\title{
The Effects of Puppet in Eduwebtv Programmes on Children's National Language Speaking Skills
}

\author{
D.O.I - 10.51201/Jusst/12475 \\ https://doi.org/10.51201/12475
}

\author{
Loy Chee Luen, Goh Swee Choo, Nor Mashitah Mohd Radzi, \\ Nordin Mamat, Wong Kung Teck \&Wong Yu Hoi \\ Faculty of Human Development, \\ Universiti Pendidikan Sultan Idris, Malaysia \\ Mohd Mahzan Awang \\ Faculty of Education \\ Universiti Kebangsaan Malaysia
}

\begin{abstract}
:
The objective of this study was to investigate the differences between children's National language speaking skills in terms of words, phrases, and sentences between the treatment group and control group. The duration of this study was three weeks. Sixty four children from two classes of primary one, government school in Malaysia were selected as the respondents in this study. This study adopted the quasi-experimental research design with one treatment group and one control group of thirty children, respectively. The treatment group learned speaking skills through Puppet in EduWebTV Programmes, while the control group learned speaking skills without Puppet in EduWebTV Programmes. The findings of the study revealed that the learning of speaking skills through Puppet in EduWebTV Programmes is more effective in increasing the skills in words, phrases, and sentences than the learning without Puppet in EduWebTV Programmes. Learning National language speaking skills with Puppet in EduWebTV Programmes has given a positive impact based on the fact that the puppets need to be used to improve children's speaking skills.
\end{abstract}

Key Words: Puppet, TV Programmes, National Language, Speaking Skills, Primary School, Children

\section{Introduction}

Many past studies highlighted the importance of learning National language as one of the national identity symbols (Awang et al. 2013; Hamid et al. 2020). It has been clearly stated in the Malaysian Government that:

"Article 152 of the constitution explains that the Malay language known as the official language is the language that cannot be disputed on its functions and its role as the national language. The position of the Malay language as the official language stabilised further with the National Language Act 1967. Its importance as a language of knowledge and the medium of teaching and learning has also led to the Education Act 1961 (revised 1996). But at the same time other languages used by other races in Malaysia, is free to be used such as Mandarin by the Chinese and Tamil by the Indians. Apart from that, English had still dominated the language in the trade and industry sector in the country. 


\begin{abstract}
The Malaysian Government also encourages its people to master other international languages particularly, in tourism and international trade The Malaysian Administrative Modernisation and Management Planning Unit, 2020, p.1"
\end{abstract}

In order to educate children in mastering National language, fun-learning approach is essential. One of the infinitives that has been formulated in Malaysia to enhance children ability to learn National language effectively is Puppet in EduWeb TV programmes. Many literature support that the use of Puppets is effective pedagogical tool in for children to learn many languages. The use of puppets also helps teachers to teach in class and encourage children's participation in the learning process (Hikmah Nur, 2017; Hayatun, Bustami \& Asnawi, 2018; Majaron, 2012; Remer \& Tzuriel, 2015; Quintero, 2011). To date, there have been no educational video programmes that used Puppet in EduWebTV Programmes to teach National language speaking skills to children from primary one, government school in Malaysia. Children in Malaysia are faced with problems in learning Malay language skills, but given the appropriate support materials such as Puppet in EduWebTV Programmes in teaching and learning sessions, they can master language skills well. Puppet in EduWebTV Programmes,introduced in 2019 by the Education Technology Division, Ministry of Education Malaysia, is said to be able to increase children's speaking skills which encompasass words, phrases, and sentences. Puppet in EduWebTV Programmeshelps teachers to achieve the objectives listed in the National Primary School Standard Curriculum.The revived National language curriculum has been implemented since 2011. The objective of this study was to identify the differences of children's speaking skills with Puppet in EduWebTV Programmes in terms of words, phrases, and sentences between the treatment group and the control group.

\title{
Literature Review
}

Children's speaking skills allow them to communicate and interact verbally with other children as well as adults. Therefore, teachers need to take the initiative to diversify the methods of teaching and learning the language. One of the ways is through the use of puppets in EduWebTV, an internet education television published by the Education Technology Division, Ministry of Education Malaysia. Kroflin (2012) argues that puppet activities can train children's language skills particularly speaking skills.

According to Vygotsky (1978), Berk and Winsler (1995), in the process of learning, children use language to generate thoughts and interact with other children as well as adults. They speak using simple and short verses. In this study, puppets in EduWebTV provide an opportunity for them to interact and learn English speaking skills by recognizing simple words and sentences.

Hayatun, Bustami and Asnawi (2018) conducted an experimental study on the use of puppets to improve the speaking and motivational skills of children. The study found out that the use of puppets as a tool in teaching language skills was more effective than teaching without using puppets. Particularly, the children's level of motivation increased when puppets were used as a pedagogical tool.

Hikmah Nur (2017) conducted a study which aimed to examine the effectiveness of the use of puppets in the teaching of children's speaking skills. Several benefits of utilizing the tool for such purpose were discussed. Through observations, interviews, and note-takings, it was found out that puppets were evidently an appropriate and highly effective language tool to be 
used in the teaching of children's speaking skills. In addition, it was also discovered that children were able to express their opinions and speak in front of others with a distinctively higher confidence when the use of puppets was incorporated in the learning process.

Padmini Rangatajan (2011) stated that puppets are a suitable tool for teaching language skills to children. The findings of her study revealed that puppets were preferred by every child to other language tools as the use of puppets attracted their attention in the learning process. The researcher further argued that language teachers can use puppets to teach easy letters, words, and sentences through the use of puppets.

The findings from all the three studies above solidify the fact that puppets are a highly effective tool to be used in improving children's speaking skills. Therefore, it is desirable that Puppet in EduWebTV Programmes will be implemented to improve the ability to speak National language for year one primary school children. With the use of internet, children can access Puppet in EduWebTV Programmes to learn National language. This learning method can provide a new dimension of language learning especially speaking skills.

\section{Methodology}

Three National language speaking skills tested by Puppet in EduWebTV Programmes in terms of words, phrases, and sentences were assessed in this research. Three different check lists were used to identify the children's speaking skills. The duration of this research was three weeks. Sixty children from two primary one classes were selected to be the respondents. This research adopted quasi-experimental research designwith the treatment group and control group of thirty children, respectively. The treatment group learned speaking skills with Puppet in EduWebTV Programmes, while the control group learned speaking skills without Puppet in EduWebTV Programmes.

\section{Finding}

The findings of the study demonstrated that teaching National language speaking skills with the use of Puppet in EduWebTV Programmesis more effective in increasing the skills of words, phrases, and sentences compared to the teaching method without it.

1. The National language speaking skills with Puppet in EduWebTV Programmes in term ofwords

Table 1

The t-test for the independent respondents concerning the National language speaking skills in terms of words for children taught with Puppet in EduWebTV Programmes and the words without Puppet in EduWebTV Programmes

\begin{tabular}{lllllll}
\hline $\begin{array}{l}\text { Construct } \\
\text { (Dependent } \\
\text { Variable) }\end{array}$ & $\begin{array}{l}\text { Factor } \\
\text { (Independent Variable) }\end{array}$ & N & Mean & SD & t & Sig \\
\hline & & & & & & \\
Words & Puppet in EduWebTV Programmes & 32 & 2.44 & .716 & -2.871 & .007 \\
& Without Puppet in EduWebTV Programmes & 32 & 1.91 & .777 & & \\
& & & & & & \\
\end{tabular}

Table 1 illustrates the respondents' independent t-test that was carried out to compare the speaking skills in terms of words for children taught with and without Puppet in EduWebTV 
Programmes. The results revealed that there is a difference between the speaking skills in terms of words taught with and withoutPuppet in EduWebTV Programmes. The children taught with Puppet in EduWebTV Programmesachieved the mean of 2.44 and SD $=.716$. On the other hand, the children taught without Puppet in EduWebTV Programmes achieved the mean of 1.91 and $\mathrm{SD}=.777$. The findings of the t-test for these independent respondents proved that the use of Puppet in EduWebTV Programmes as a pedagogical tool in teaching the speaking skills in terms of words is more effective than that without the Puppet in EduWebTV Programmes.

2. The National language speaking skills with Puppet in EduWebTV Programmes in term of phrases

Table 2

The t-test for the independent respondents concerning the National language speaking skills in terms of phrases for children taught with and without Puppet in EduWebTV Programmes

\begin{tabular}{lllllll}
\hline $\begin{array}{l}\text { Construct } \\
\text { (Dependent } \\
\text { Variable) }\end{array}$ & $\begin{array}{l}\text { Factor } \\
\text { (Independent Variable) }\end{array}$ & N & Mean & SD & t & Sig \\
\hline \multirow{3}{*}{ Phrases } & Puppet in EduWebTV Programmes & 32 & 2.25 & .568 & -2.350 & .025 \\
& $\begin{array}{l}\text { Without Puppet in EduWebTV } \\
\text { Programmes }\end{array}$ & 32 & 1.91 & .777 & & \\
& & & & & & \\
\end{tabular}

Table 2 displays the respondents' independent t-test that was carried out to compare the National language speaking skills in terms of phrases for children taught with and without Puppet in EduWebTV Programmes. The results of the analysis established that there is a difference in the achievement of speaking skills in terms of phrases between the two groups of children. The children taught with Puppet in EduWebTV Programmesachieved the mean of 2.25 and SD $=.568$ and those taught without Puppet in EduWebTV Programmes achieved the mean of 1.91 and $\mathrm{SD}=.777$. The findings of the t-test for these independent respondents substantially proved that using Puppet in EduWebTV Programmes as a teaching tool for speaking skills in terms of phrases is more effective than the teaching without Puppet in EduWebTV Programmes.

3. The National language speaking skills with Puppet in EduWebTV Programmes in terms ofsentences

Table 3

The t-test for the independent respondents concerning the National language speaking skills in terms of sentences for children taught with and without Puppet in EduWebTV Programmes

\begin{tabular}{lllllll}
\hline $\begin{array}{l}\text { Construct } \\
\begin{array}{l}\text { Dependent } \\
\text { Variable) }\end{array}\end{array}$ & $\begin{array}{l}\text { Factor } \\
\text { (Independent Variable) }\end{array}$ & N & Mean & SD & t & Sig \\
\hline Sentences & $\begin{array}{l}\text { Puppet in EduWebTV Programmes } \\
\text { Without Puppet in EduWebTV }\end{array}$ & 32 & 2.44 & .716 & -3.215 & .003 \\
& $\begin{array}{l}\text { Programmes } \\
\end{array}$
\end{tabular}


Table 3 exemplifies the respondents' independent t-test carried out to compare National language speaking skills in terms of sentences for children taught with and without Puppet in EduWebTV. The results of the analysis established that there is a difference in the achievement of speaking skills between the two groups of children. The children taught with Puppet in EduWebTV Programmes achieved the mean of 2.44 and $\mathrm{SD}=.716$. On the contrary, the children taught withoutPuppet in EduWebTV Programmes achieved the mean of 2.06 and SD $=.619$. These suggest that the teaching with Puppet in EduWebTV Programmesis more effective compared to that without the Puppet in EduWebTV Programmes.

\section{Discussion and Conclusion}

All in all, the study could conclusively state that the teaching of National language speaking skills with the use of Puppet in EduWebTV Programmes for words, phrases, and sentences is more effective than the teaching without it. The findings also were consistent with that of Hayatun, Bustami and Asnawi (2018), Hikmah Nur (2017) and Padmini Rangatajan (2011) that the teaching method using Puppet in EduWebTV Programmes can improve children's speaking skills. This study proposes a few recommendations regarding to the language learning activities which could be conducted for children in primary school. It can be used as part of co-curriculum activities as past studies revealed that learning language is one of the leadership aspects that can be integrated via co-curriculum activities (Ghani, Awang, Ajit \& Rani 2020). For educators who are interested in utilizing puppets in language learning, they should use different types of puppets such as finger puppets, shadow puppets, string puppets, and rod puppets in order to create a fun learning experience in the classroom. To gain more objectivity, further research can be conducted using different methods and approaches. Additionally, the data could also be collected from more perspectives to improve the rigor of the research. Finally, other language skills such as listening, reading, and writing can also be examined to enrich the body of knowledge.

\section{Acknowledgement}

The researchers would like to acknowledge the Education Technology Division, Ministry of Education Malaysia and Research Management and Innovation Centre, Universiti Pendidikan Sultan Idris for the Education Based University Research Grant (2018-0237-107-01) and Faculty of Education, the National University of Malaysia for the support of this publication.

\section{References}

Awang, M.M., Ahmad, A.A., Bakar, N.A, Ghani, S.A., Yunus, A.N.M., Ibrahim, M.A.H., Ramalu, J.C., Saad, C.P., Rahman, M.J.A. (2013). Students' Attitudes and Their Academic Performance in Nationhood Education. International Education Studies, 6(11), 21-28

Berk, L., \& Winsler, A. (1995). Scaffolding children's learning: Vygotsky and early childhood learning. Washington, DC: National Association for Education of Young Children.

Ghani S.A., Awang M.M., Ajit G., Rani M.A.M. (2020). Participation in Co-Curriculum Activities and Students' Leadership Skills. Journal of Southwest Jiantong University,55(4), pp 5342-5350 
Hamid, N.H.,Awang, M.M., Ahmad, A.R.,Ghani S.A., Alfitri., Linang, C.L. (2020).Education for Rural Community:Utliisation of Sosial Media Among Multi-Ethnic Students in Malaysian Borneo.2020.Hamdard Islamicus, 43(1), pp 912919

Hayatun Fauza, Bustami Usman \& Asnawi Muslem. (2018). Improving students' speaking skilkl and motivation by using hand puppet show media. English Education Journal, 9 (2), 216-228.

Hikmah Nur Insani. (2017). The use of puppet in teaching speaking to young learners. Proceeding of the CONAPLIN and ICOLLITE, 683-688).

Kementerian Pendidikan Malaysia. (2017). Kurikulum Standard Sekolah Rendah: Bahasa Melayu Tahun 1. Putrajaya: Kementerian Pendidikan Malaysia.

Kroflin, L. (2012). The role of puppet in language teaching. In Kroflin, L. (Eds.). The power of the puppet (pp. 46-62). Zagreb: The UNIMA Puppets in Education, Development and Therapy

Majaron, E. (2012). Art as a pathway to child. In Kroflin, L. (Eds.). The power of the puppet (pp. 11-17). Zagreb: The UNIMA Puppets in Education, Development and Therapy Commission.

Majaron, E. (2012). Art as a pathway to child. In Kroflin, L. (Eds.). The power of the puppet (pp. 11-17). Zagreb: The UNIMA Puppets in Education, Development and Therapy Commission.

Padmini Rangatajan. (2011, March). Puppets: A good language teacher-part 1. Teachers dot com Teaching Transactions, 3-4.

Quintero, B.S. (2011). Puppetry and art education: a personel journey. Unpublished MA thesis, University of Iowa.

Remer, R. \& Tzuriel, D. (2015). "I teach better with the puppet"- Use of puppet as a mediating tool in kindergarten education-an evaluation. American Journal of Educational Research, 3 (3), 356-365.

The Malaysian Administrative Modernisation and Management Planning Unit. (2020). Official Language. Accessed Online on the 16 ${ }^{\text {th }}$ December 2020: https://www.malaysia.gov.my/portal/content/30118

Vygotsky, L. S. (1978). Mind in society: The development of higher psychological processes. Cambridge, MA: Harvard University Press. 